Vol. 7(6), pp. 221-224, J une 2015

DOI: 10.5897/J VMAH2015.0383

Artic le Number: 35BB51852993

ISSN 2141-2529

Copyright $\odot 2015$

Author(s) reta in the copyright of this artic le

http://www.academicjouma ls.org/J VMAH

Journal of Veterinary Medicine and

Animal Health

\title{
Prevalence of endoparasitic helminths of donkeys in and around Haramaya district, Eastern Ethiopia
}

\author{
Biniam Tsegaye ${ }^{*}$ and Abdisa Chala \\ College of Veterinary Medicine, Haramaya University, P.O.Box 138, Dire Dawa, Ethiopia.
}

Received 20 March, 2015; Accepted 20 May, 2015

\begin{abstract}
A cross sectional study was conducted to determine the prevalence of endoparasites of donkeys in and around Haramaya district, East Hararghe zone of Oromia regional state. Coprological examination was carried out on fecal samples collected from 384 donkeys. Simple flotation, sedimentation and fecal culture techniques were used for the detection of eggs and larvae of helminth parasites. The overall prevalence of endoparasitic infection was $93.75 \%(n=360)$. Four species of helminths: Parascaris equorum (20.5\%), Fasciola species (15.36\%), Oxyuris equi (15.36\%) and Dictyocaulus arnfieldi (21.88\%) and two genera (Strongylus and Trichonema), were encountered. Identification of $L_{3}$ of nematodes from coprocultured faeces of donkeys showed the predominance of strongyles species (65\%), Dictyocaulus Arnfieldi (25\%), and Oxyuris equi (10\%). The high prevalence of helminth parasites noted in this study calls for regular monitoring and intervention measures such as strategic deworming of donkeys.
\end{abstract}

Key words: Endoparasitic helminths, Haramaya district, prevalence.

\section{INTRODUCTION}

Ethiopia claimed to have the largest livestock population in Africa, with an estimated population of 47.5 million cattle, 26.1 million sheep, 21.7 million goat, 7.8 million equines out of which 5.42 million are donkeys, 1 million camel and 39.6 million chickens (CSA, 2009). These include rampant animal diseases, poor nutrition, poor husbandry, poor infrastructure, and shortage of trained man power and lack of government policies (PACEEthiopia, 2003). Among the livestocks, donkeys are tolerant to hot, arid environments where the agriculture is subsistence and are popular among pastoralists. It has been suggested that donkeys can comfortably pull more weight than they can carry provided that the harness is suitable (Saul et al., 1997), but their health aspect have been ignored (Taylor et al., 2007).

Parasitic helminthes are one of the most common factors that constrain the health and working performance of donkeys worldwide (Zerihun et al., 2011). Some of them are active bloodsuckers and cause various degrees of damage depending on the species and numbers present, nutritional and the immune status of equids. Though, the available information suggests that gastrointestinal helminthes are the main reason for early demises of donkey (Zerihun et al., 2011). There are more than 150 species of helminth parasites that can infect donkeys. The most common and troublesome are: large 
strongyles, small strongyles, roundworms, tapeworms, lungworm, pinworms, threadworms and bots. Probably the most important in terms of health risk are the large and small strongyles, roundworms and tapeworms (Radostits et al., 2007).

Some works have been done in different parts of the country such as: Endoparasites of donkeys in Sululta and Gefersa Districts by Zerihun et al. (2011), strongyles and parascaris parasites population in working donkeys of Central Shoa by Ayele and Dinka (2010), occurrence of lungworm infection in equine, and their risk factors in and around Jimma town by Tihitna et al. (2012) and prevalence of gastro-intestinal parasites of donkeys in Dugda Bora District by Ayele et al. (2006). However, there has not been any study conducted in the study area. Therefore, the objectives of the study were: to determine the prevalence of helminth parasites of donkeys in and around Haramaya District, and to identify species of gastro-intestinal helminthes recovered from selected samples.

\section{MATERIALS AND METHODS}

\section{Description of study area}

The study was conducted in and around Haramaya district, eastern Hararghe zone, Oromia regional state, Ethiopia. It is located about $507 \mathrm{kms}$ away from Addis Ababa to east and $14 \mathrm{kms}$ west of Harar town. The altitude of the district ranges from 1400 to 2340 m.a.s.l. Geographically, the area is located at $41^{\circ} 59^{\prime} 58^{\prime \prime} \mathrm{N}$ latitude and $09^{\circ} 24^{\prime} 10^{\prime \prime} \mathrm{E}$ longitudes. It receives an annual rain fall approximately $900 \mathrm{~mm}$ and climatically the district has two ecological zones of which 66\% mid land and 33.3\% low land (CSA, 2009).

\section{Study animals}

The study was conducted on donkeys that came to the different markets in and around the Haramaya district. Donkeys of different age, sex and body condition score were tried to be included in the study. The body condition score was done according to Henneke (1983).

\section{Study design}

A Cross-sectional study was conducted to determine the prevalence of gastrointestinal helminth parasites of donkeys in the study areas.

\section{Sampling method and sample size determination}

By using simple random sampling methods and 95\% confidence interval, the sample size was calculated using the formula of Thursfield (2005).

$n=\frac{1.96^{2} P \exp (1-\text { Pexp) }}{d^{2}}$

Where; $\mathrm{n}=$ required sample size,

Pexp = expected prevalence, $d=$ required precision (usually 0.05 )

By using an expected prevalence of $50 \%$, a total 384 donkeys were included in the study.

\section{Study methodology}

\section{Coprological examination}

The fecal samples were collected directly from the rectum of the donkeys by using rectal gloves or from freshly passed droppings. Each sample was labeled with animal identification, owner's name, date and area of collection with indelible pen. After collecting, the sample was transported to Haramaya University parasitology laboratory for immediate processing and examination of the sample. The observation of helminth parasites eggs in the faeces of the donkeys was evaluated by using the coprological flotation and sedimentation techniques (MAFF, 1979).

\section{Fecal culture}

Fecal culture was done for 65 positive fecal samples according to Bowman (2003) to appreciate the gastrointestinal helminths parasites larvae profile. Identification of larvae $\left(L_{3}\right)$ was based on the shape and gut cells, relative size of sheath tail and shape of tail of larvae (Zerihun et al., 2011).

\section{Data management and analysis}

The datas were entered into Microsoft excel 2007 spread sheets and were analyzed using STATA (version 11) statistical software package. The association of infection with the different variables was analyzed using $x^{2}$ test. A statistically significant association between variables is considered to exist if the calculated $p$-value was less than 0.05 with $95 \%$ confidence level.

\section{RESULTS}

From the total of 384 donkeys, 360 were infected with an overall prevalence of $93.75 \%$ (Table 1). The prevalence of helminthes parasites in the study area showed that Strongyle species were with higher prevalence (84.89\%) followed by Trichonema species $(23.44 \%), D$. arnfieldi $(21.88 \%), P$. equorum $(20.5 \%), F$. hepatica and $O$. equi with $15.36 \%$ each.

\section{DISCUSSION}

The result indicated that donkeys are a host to different species and genera of helminth parasites. The prevalence of strongyles disagrees with the result of $99.5 \%$ by Zerihun et al. (2009), a $100 \%$ report by Alemayehu (1995), $96.77 \%$ by Sinasi (2009), $92 \%$ by Ayele and Dinka (2010), and $65.1 \%$ by Hussen (2011). This may be due to the differences in the agro-ecological and climatic conditions between the study areas. The prevalence of Trichonema species (23.44\%) in the study was higher than the $15.85 \%$ reported by Shrikhande et al. 
Table 1. Prevalence of helminth parasites by month, sex, age and body condition of the animals in the study sites along with their statistical significance.

\begin{tabular}{llccccc}
\hline parameter & Variables & Animals examined & No. of positive & Prevalence (\%) & $\mathbf{X}^{2}$ & p-value \\
\hline \multirow{4}{*}{ Month } & December & 55 & 52 & 94.55 & & \\
& January & 184 & 173 & 94.02 & & \\
& February & 120 & 112 & 93.33 & 0.2488 & 0.969 \\
& March & 25 & 23 & 92.0 & & \\
& Total & 384 & 360 & 93.75 & & \\
\multirow{5}{*}{ Sex } & & & & & & \\
& Female & 120 & 113 & 94.17 & & \multirow{6}{*}{ Age } \\
& Male & 264 & 247 & 93.56 & 0.0517 & 0.820 \\
& Total & 384 & 360 & 93.75 & & \\
& & & & & & \\
& Young & 65 & 59 & 90.77 & & \\
& Adult & 319 & 301 & 94.36 & 1.1865 & 0.276 \\
& Total & 384 & 360 & 93.75 & & \\
& & & & & & \\
& Pood & 163 & 157 & 96.32 & 25.28 & 0.00 \\
& Fair & 156 & 151 & 96.79 & & \\
& Good & 65 & 52 & 80.0 & & \\
\hline
\end{tabular}

(2009). This may be due to the management system and nature of the grazing area. The current prevalence of $D$. arnfieldi $(21.88 \%)$ in the study area was greater than the reports of $9.67 \%$ by Sinasi (2009), 3.65\% of Shrikhande et al. (2009) and $13.8 \%$ by Tihtina et al. (2012). This difference could be due to the difference in environmental conditions and management practice favoring the survival of the larvae of the parasite.

The prevalence of $P$. equorum (20.5\%) recorded in this study, was higher than the previous report of $17.3 \%$ by Fikru et al. (2005) but less than the results of $29.26 \%$ by Shrikhande et al. (2009), 43\% reported by Ayele et al. (2006) and $22.58 \%$ reported by Sinasi (2009). This may be due to the agro-ecological and climatic difference of the study areas and lack of awareness about the health animals. The prevalence of $O$. equi was higher than the $8.53 \%$ report by Shrikhande et al. (2009) and 6.4\% reported by Sinasi (2009). This may be due to the climatic difference between the study areas and the management systems. The prevalence for F. hepatica was higher than the previous report of $1.5 \%$ by Ayele et al. (2006) in Dugda Bora district. This higher prevalence suggests that $F$. hepatica is common in highlands where donkeys share the same grazing area with ruminants that are considered as primary host of liver fluke and favorable ecological conditions which allow multiplication and spread of intermediate snail host in the district.

The higher prevalence in adult donkeys in the study disagrees with the result of Zerihun et al. (2011). This may be due to high risk of getting infection from the market and other work areas. In Haramaya district the seasonal differences between months have no a great effect on the prevalence of equine helminth parasites. This may be due to the presence of almost similar climatic condition between the months and because of the permanent marshy grazing field in the study area. This result disagreed with the reports of Hussen (2011). This may be due to agro-ecological and climatic difference between the study areas. There was a significant difference in helminth prevalence on the basis of body condition score which was in agreement with previous reports by Matthee et al. (2002), Getachew et al. (2009) and Brady and Nichols (2009).

\section{Conclusion}

The study revealed a high prevalence of a wide range of species of gastro-intestinal helminths parasites that play a great role in confronting the health and welfare of donkeys in and around Haramaya district. The result also suggests the presence of favorable environmental condition for the survival, infection and perpetuation of helminthes of donkey in the district.

\section{Conflicts of interest}

The authors declare that they have no conflicts of interest.

\section{REFERENCES}

Alemayehu $\mathrm{H}$ (1995). Prevalence of equine helminthiasis in specific 
sites of Arsi and Bale regions. DVM Thesis. Debre Zeit Ethiopia.

Ayele G, Dinka A (2010). Study on strongyles and parascaris parasites population in working donkeys of central Shoa, Ethiopia. Livest. Res. Rural Dev. 22(12):1-5.

Ayele G, Feseha G, Bojia E, Joe A (2006). Prevalence of gastrointestinal parasites of donkeys in Dugda Bora District, Ethiopia. Livest. Res. Rural Dev. 18:2-6.

Brady HA, Nichols WT (2009). Drug resistance in equine parasites : An emerging global problem. J. Equine. Vet. Sci. 29:285-295.

CSA (2009). Federal Democratic Republic of Ethiopia; Agricultural sample enumeration statistical abstract.

Bowman DD (2003). Georgi's parasitology for veterinarians eighth edition, Elsevier pp. 200-205.

Fikru R, Reta D, Teshale S, Bizunesh M (2005). Prevalence of equine gastrointestinal parasites in western highlands of Oromia. Bull. Anim. Health Prod. Afr. 53:161-166.

Getachew M, Feseha G, Trawford A, Reid SWJ (2009). A survey of seasonal patterns in strongyle fecal worm egg counts of working equids of the central midlands and lowlands, Ethiopia. Trop. Anim. Health Prod. 40:637-642.

Hussen S (2011). Prevalence of equine stongylosis in Kombocha town, South Wollo Administrative Zone, Amhara National Regional State, Ethiopia. DVM Thesis, Haramaya University.

MAFF (1979). Manual of Veterinary Laboratory Techniques, Technical Bulletin, No. 18, ministry of Agricultural Fisheries and Food, London $\mathrm{p}$ 14.

Matthee S, Krecek RC, Milne SA, Boshoff M, Guthrie AJ (2002).Impact of management interventions on helminth levels and body and blood measurements in working donkeys in South Africa. Vet. Parasitol. 107:103-113.

PACE-Ethiopia (2003). Experiences and the way forward on community based animal health service delivery in Ethiopia. Proceeding of a workshop held in Addis Ababa, Ethiopia.
Radostits OM, Gay CC, Hinchcliff KW, Constable PD (2007). Veterinary Medicine. A textbook of the diseases of cattle, sheep, goats, pigs and horses. $10^{\text {th }}$ edition. Saunders-Elsevier pp. 1311-1315.

Saul C, Siefert L, Opuda AJ (1997). Diseases and health problems of donkeys: a case study from 5-9 May. Debre Zeit, Ethiopia.

Shrikhande GB, Rewatkar SG, Deshmukh SS, Maske DK, Raghorte YM (2009). The Incidence of Helminth parasites in Donkeys. Vet. World. 2(6):224.

Sinasi U (2009). A survey on helminth infections of equines in the Central Black Sea region, Turkey. J. Vet. Anim. Sci. 33(5):373-378.

Taylor MA, Coop RL, Wall RL (2007). Veterinary parasitology third edition Wiley-Blackwell publishing company pp. 259-314.

Thursfield M (2005). Veterinary Epidemiology. $3^{\text {rd }}$ edition London. WileyBlackwell p 233.

Tihtina S, Basaznew B, Mersha C, Achenef M (2012). Occurrence of Lung Worm Infection in Equine and Their Associated Risk Factors. Glob. Vet. 8(1):35-38.

Zerihun A, Bersissa K, Bojia E, Ayele G, Tesfaye M, Etana D (2011). Endoparasites of donkeys in Sululta and Gefersa Districts of Centeral Oromia, Ethiopia. J. Anim. Vet. Adv. 10(14):1850-1854. 